\title{
Quantifying variable rainfall intensity events on runoff and sediment losses
}

\author{
C. C. $\operatorname{Truman}^{1}$, T. L. Potter $^{1} \&$ R. C. Nuti ${ }^{2}$ \\ ${ }^{1}$ USDA-ARS, Tifton, USA \\ ${ }^{2} U S D A-A R S$, Dawson, USA
}

\begin{abstract}
Coastal Plain soils in Georgia are susceptible to runoff, sediment, and chemical losses from short duration-high intensity, runoff producing storms at critical times during the growing season. We quantified runoff and sediment losses from a Tifton loamy sand managed under conventional- (CT) and strip- (ST) tillage and planted to peanuts. Simulated rainfall was applied at planting, 30 days after planting, and after harvest during the peanut growing season with rainfall events comprised of variable intensity $\left(I_{v}\right)$ patterns representative of each time or season (spring $=I_{V S P R}$, summer $=I_{v S U M}$, fall $=I_{V F A L L}$ ). Simulated rainfall was applied to $2 \times 3-$ $\mathrm{m}$ plots $(\mathrm{n}=3)$ for each treatment. Runoff and sediment were measured from each 6- $\mathrm{m}^{2}$ plot. Runoff ranged from $9-22 \%$ of the rainfall applied for the three events. The most runoff occurred from CT- $\mathrm{I}_{\mathrm{VFALL}}$ plots; the least occurred from ST- $\mathrm{I}_{\mathrm{VSUM}}$ plots. Maximum runoff rates were $7-20 \%$ of the maximum intensity and occurred 3-8 min after maximum intensity peaks. Sediment yields ranged from $105-1420 \mathrm{~kg} \mathrm{ha}^{-1}$. The most sediment occurred from CT-I $\mathrm{I}_{\mathrm{vSPR}}$ plots; the least occurred from ST-I $\mathrm{I}_{\mathrm{vSum}}$ plots. Runoff and sediment curves had similar shapes as their corresponding rainfall intensity pattern. As for tillage, CT plots had 38\% more runoff and 2.7-fold more sediment than ST plots over the three events. The largest difference in runoff (2.4-fold) and sediment (3.8-fold) among CT and ST plots occurred in the fall ( $\left.\mathrm{I}_{\mathrm{VFALL}}\right)$. Results improve our understanding of when runoff, sediment, and chemical losses are highest at critical times during a peanut growing season, and show how ST is effective in limiting those losses.
\end{abstract}

Keywords: erosion, rainfall partitioning, rainfall simulation. 


\section{Introduction}

Peanut production is vital to Georgia agriculture, both economically and as a rotational crop for traditional row-crop producers. Georgia accounts for $49 \%$ of the peanut production in the U.S., with planted acreages of $231,000+$ ha annually (Georgia Peanut Commission [1]). Most ( $>90 \%$ ) of peanut production in Georgia occurs in the Coastal Plain region on highly-weathered, relatively sandy soils. Coastal Plain soils, traditionally cropped under conventional tillage (CT) practices, tend to be drought-prone, and are susceptible to compaction and runoff, sediment, and chemical losses. Rainfall in the Coastal Plain $(\sim 1250 \mathrm{~mm}$ $\mathrm{yr}^{-1}$ ) tends to have short duration-high intensity, runoff producing storms especially at critical times during the growing season when antecedent water content is high and/or soil cover (residue, canopy) is none to minimal.

Conservation tillage (strip tillage, ST) adoption in the Coastal Plain region of Georgia has increased because ST systems accumulate surface residue, enhance infiltration, and reduce runoff and sediment losses (Reeves [2]; Truman et al. [3]; Truman and Nuti [4]). However, studies have reported less runoff from CT than from ST, especially 1-3 yrs after ST adoption due to increased consolidation with time (Radcliffe et al. [5]; Cassel and Wagger [6]). Consequently, paratilling, a non-inversion, deep tillage technique, is often used in the Southeast in ST systems to disrupt dense, water-restrictive subsurface layers. Disrupting consolidated horizons or layers with paratilling reduces bulk density, and increases infiltration and reduces runoff (Truman et al. [3]). In the Coastal Plain region of Georgia, land managed in ST and planted to peanuts is generally paratilled in the fall prior to planting peanuts the following spring.

Natural rainfall is spatially and temporally variable (Bosch et al. [7]; Frauenfeld and Truman [8]). Frequency of severe rainfall events has increased throughout the U.S., mainly in the form of increased intensity of extreme rainfall events (Nearing et al. [9]; Todd et al. [10]). Changes in rainfall intensity within a storm affect how rainfall is partitioned (infiltration, runoff) and sediment and chemical transport (Truman et al. [3]; Frauenfeld and Truman [8]; Nearing et al. [9]; Franklin et al. [11]; Potter et al. [12]).

In the Coastal Plain region of Georgia, data are limited on effects of peanut cropping systems on runoff and sediment yields. Truman and Williams [13] used simulated rainfall $\left(63.5 \mathrm{~mm} \mathrm{~h}^{-1}\right)$ to evaluate runoff and soil loss from single- and twin-row peanuts throughout the growing season. They found that single-row peanuts had as much as 3-times more runoff and soil loss than twin-row peanuts. Twin-row peanuts maximized canopy development and percent soil cover early in the growing season and minimized the time in which bare soil is vulnerable to a runoff producing rainstorm. They did not evaluate peanut production under strip-till nor with variable rainfall intensities common during the growing season. We quantified runoff and sediment from a Tifton loamy sand managed under CT and ST and planted to peanuts at three times during the peanut growing season (at planting, 30 days after planting, after harvest) with rainfall simulation events with variable rainfall intensities representative of each time period (spring, summer, fall). 


\section{Materials and methods}

The field site was located near Tifton, GA ( $\left.\mathrm{N} 31^{\circ} 26^{\prime}, \mathrm{W} 83^{\circ} 35^{\prime}\right)$ on a Tifton loamy sand (Typic Kandiudult; $82 \%$ sand, 7\% clay; 2\% slope). The site has been managed under CT and ST in a cotton (Gossypium hirsutum)-peanut (Arachis hypogea) rotation since 1998 (Truman and Nuti [4]). CT consisted of fall disking, winter rye (Secale cerale) cover, followed by spring disking, mouldboard plowing, field cultivator levelling, and bedding. Rye surface cover was incorporated $10-15 \mathrm{~cm}$. ST consisted of planting a winter rye cover just after crop harvest in the fall and killing the rye chemically 30 days before planting the next year's row crop. All ST plots were paratilled $($ depth $=\sim 30 \mathrm{~cm})$ in the fall $(11$ October, 2007) prior to the 2008 peanut growing season. With ST, a 10-cm wide strip was tilled and used to plant the crop into. In 2008, this site was cropped to single-row peanuts (planted 12 May, $0.9 \mathrm{~m}$ row spacing). Surface residue cover for CT and ST were $<1$ and $50 \%$, respectively.

Rainfall simulation plots (2-m wide, 3-m long) were established on each treatment at three critical times during the 2008 peanut growing season: $13-20$ May (at planting); 23-26 June (first fungicide application); and 21-31 October (immediately after harvest). Each $6-\mathrm{m}^{2}$ plot consisted of a wheel track and two half beds on either side of the wheel track.

Simulated rainfall was applied with an oscillating nozzle rainfall simulator (Truman and Nuti [4]) that used 80150 Veejet nozzles (2.3-mm median drop size), and was placed $3-\mathrm{m}$ above each $6-\mathrm{m}^{2}$ plot. Simulated rainfall was applied at three variable rainfall intensity (I) patterns: a spring time pattern at planting $\left(\mathrm{I}_{\mathrm{vspr}}\right)$; a summer time pattern at the first fungicide application $\left(\mathrm{I}_{\mathrm{vsum}}\right)$; and a fall time pattern at harvest $\left(\mathrm{I}_{\mathrm{vfall}}\right)$ (Fig. 1). Data from the $\mathrm{I}_{\mathrm{vspr}}$ pattern have been reported previously (Potter et al. [14]).

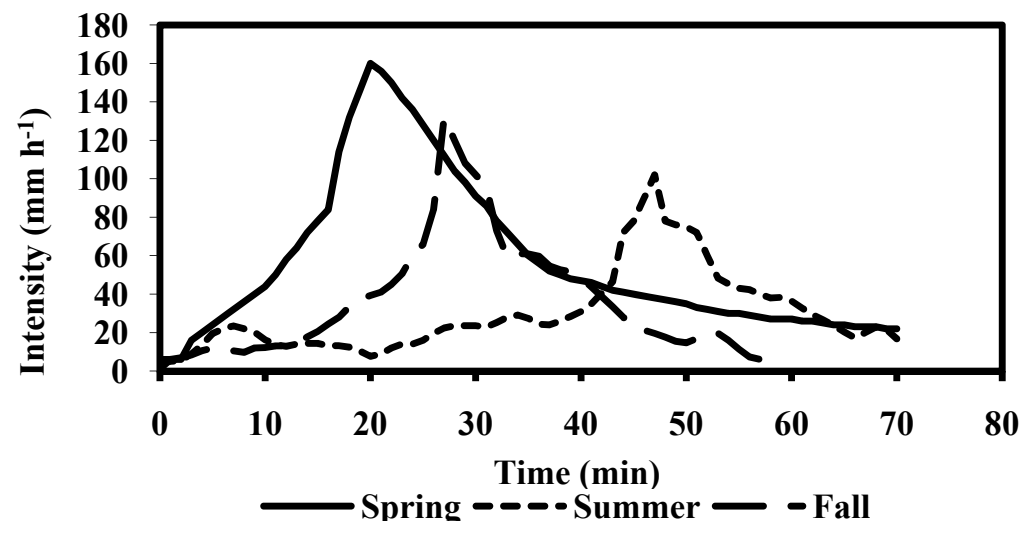

Figure 1: $\quad$ Simulated variable rainfall intensity patterns evaluated. 
All variable rainfall intensity patterns were developed from measured 5- and 1-min natural rainfall data (30 years) collected at Tifton, GA. Natural rainfall during the spring (March, April, May), summer (June, July, August), and fall (September, October, November) were analyzed to determine the respective patterns that occurred most frequently during each 3-month season. For each season, the most frequent occurring storm was programmed into the simulator on a 1-min basis as the representative $I_{v}$ pattern for that 3-month season $\left(I_{v s p r}\right.$ for spring; $I_{v s u m}$ for summer; $I_{v f a l l}$ for fall). Rainfall duration for the $I_{v s p r}, I_{v s u m}$, and $\mathrm{I}_{\text {vfall }}$ was 70, 70, and $60 \mathrm{~min}$, respectively. Maximum rainfall I (average I) during the $I_{v s p r}, I_{v s u m}$, and $I_{v f a l l}$ was $160\left(56 \mathrm{~mm} \mathrm{~h}^{-1}\right), 102\left(30 \mathrm{~mm} \mathrm{~h}^{-1}\right)$, and 132 $\left(36 \mathrm{~mm} \mathrm{~h}^{-1}\right) \mathrm{mm} \mathrm{h}^{-1}$, respectively. Well water was used in all simulations. Runoff $(\mathrm{R})$ and sediment (E) were measured from each $6-\mathrm{m}^{2}$ plot at 5-min intervals, and determined gravimetrically.

Treatments $(n=3)$ consisted of tillage $(C T, S T)$ and rainfall intensity pattern $\left(\mathrm{I}_{\mathrm{vspr}}, \mathrm{I}_{\mathrm{vsum}}, \mathrm{I}_{\mathrm{vfall}}\right)$. Means, coefficient of variations $(\mathrm{CV}, \%)$, and standard error bars are given for measured data. Unpaired t-tests (two-tailed distribution) were used to determine significance among treatment means using SigmaStat 3.1 (Systat [15]). All test statistics were evaluated at $\mathrm{P}=0.05$, unless otherwise noted.

\section{Results and discussion}

For the spring event $\left(\mathrm{I}_{\mathrm{VSPR}}\right)$, runoff from CT and ST plots were $11-13 \%$ of the total rainfall applied (Table 1). Runoff curves (Fig. 2) had similar shapes as the $\mathrm{I}_{\mathrm{VSPR}}$ pattern. Maximum runoff was $14-18 \%$ of maximum intensity $\left(160 \mathrm{~mm} \mathrm{~h}^{-1}\right)$ and occurred 5-8 min after the $\mathrm{I}_{\mathrm{vSPR}}$ peak $(20 \mathrm{~min})$. Runoff parameters were similar for freshly tilled CT and recently paratilled ST plots. Sediment yields ranged from $637-1420 \mathrm{~kg} \mathrm{ha}^{-1}$. CT plots had 2.2-fold more sediment than ST

Table 1: Hydrology and erosion parameters for each treatment studied.

\begin{tabular}{rccccc}
\hline Treatment & $\mathrm{I}^{\mathrm{a}}$ & $\mathrm{R}_{\text {tot }}$ & $\mathrm{R}_{\max }$ & $\mathrm{E}$ & $\mathrm{E}_{\max }$ \\
\hline & $\mathrm{mL}$ & $\mathrm{mm} \mathrm{h}^{-1}$ & $\mathrm{~mm} \mathrm{~h}^{-1}$ & $\mathrm{~g}$ & $\mathrm{~kg} \mathrm{~m}^{-2} \mathrm{~h}^{-1}$ \\
CT-I $_{\text {vSPR }}$ & $1279(02)^{\mathrm{b}}$ & $6.4(13)$ & $23.2(20)$ & $852(06)$ & $0.57(08)$ \\
ST-I $_{\text {vSPR }}$ & $1299(02)$ & $7.3(08)$ & $28.7(10)$ & $382(29)$ & $0.32(27)$ \\
\hline$P$ & $\mathrm{NS}$ & $\mathrm{NS}$ & $\mathrm{NS}$ & 0.0005 & 0.0047 \\
& & & & & \\
CT-I $_{\text {vSUM }}$ & $633(03)$ & $4.3(07)$ & $20.0(11)$ & $235(20)$ & $0.28(22)$ \\
ST- $_{\text {vSUM }}$ & $626(03)$ & $2.8(11)$ & $12.2(07)$ & $63(16)$ & $0.05(34)$ \\
\hline$P$ & $\mathrm{NS}$ & 0.0070 & 0.0100 & 0.0078 & 0.0070 \\
CT-I $_{\text {vFALL }}$ & $672(01)$ & $7.7(10)$ & $25.3(04)$ & $463(05)$ & $0.71(16)$ \\
ST-I $_{\text {vFALL }}$ & $652(01)$ & $3.2(07)$ & $9.3(13)$ & $121(11)$ & $0.18(17)$ \\
\hline$P$ & 0.0317 & 0.0014 & 0.0001 & 0.0001 & 0.0028 \\
\hline
\end{tabular}

${ }^{\mathrm{a}} \mathrm{I}=$ Intensity; $\mathrm{R}_{\text {tot }}=$ total runoff; $\mathrm{R}_{\max }=$ maximum 5 -min runoff rate;

$\mathrm{E}_{\mathrm{tot}}=$ sediment yield; $\mathrm{E}_{\max }=$ maximum 5-min sediment rate.

${ }^{\mathrm{b}}$ Mean (Coefficient of Variation). 
plots. Sediment curves had similar shapes as the $I_{v S P R}$ pattern (Fig. 3). Maximum sediment rate for CT and ST plots occurred 5-6 min after the 20 min $\mathrm{I}_{\mathrm{vSPR}}$ peak. The maximum 5-min sediment rate for CT plots was $78 \%$ higher than that for ST plots.

For the summer event $\left(\mathrm{I}_{\mathrm{VSUM}}\right)$, runoff from CT and ST plots were $9-14 \%$ of the total rainfall applied (Table 1). CT plots had 54\% more runoff than ST plots. Runoff curves (Fig. 2) had similar shapes as the $\mathrm{I}_{\mathrm{vSUM}}$ pattern. Maximum runoff was $12-20 \%$ of maximum intensity $\left(102 \mathrm{~mm} \mathrm{~h}^{-1}\right)$ and occurred $3-4 \mathrm{~min}$ after the $\mathrm{I}_{\mathrm{VSPR}}$ peak $(47 \mathrm{~min})$. The maximum runoff rate for CT plots was $64 \%$ higher than that for ST plots. Sediment yields ranged from $105-392 \mathrm{~kg} \mathrm{ha}^{-1}$. CT plots had 3.7-fold more sediment than ST plots. Sediment curves had similar shapes as the $\mathrm{I}_{\mathrm{VSPR}}$ pattern (Fig. 3). Maximum sediment rate for CT and ST plots occurred 5-6 min after the 47 min $\mathrm{I}_{\mathrm{vSPR}}$ peak. The maximum 5-min sediment rate for CT plots was 5.6-fold higher than that for ST plots. Peanut canopy cover during this event averaged 10\% ( $\sim 30$ days after planting) influenced runoff and sediment losses, especially combined with surface residue cover on ST plots.

For the fall event $\left(\mathrm{I}_{\mathrm{vFALL}}\right)$, runoff from $\mathrm{CT}$ and ST plots were $9-22 \%$ of the total rainfall applied (Table 1). CT plots had 2.4-fold more runoff than ST plots. Runoff curves (Fig. 2) had similar shapes as the $\mathrm{I}_{\mathrm{vSUM}}$ pattern. Maximum runoff was $7-19 \%$ of maximum intensity $\left(132 \mathrm{~mm} \mathrm{~h}^{-1}\right)$ and occurred $\sim 8 \mathrm{~min}$ after the $\mathrm{I}_{\mathrm{VSPR}}$ peak $(27 \mathrm{~min})$. The maximum runoff rate for $\mathrm{CT}$ plots was 2.7 -fold higher than that for ST plots. Sediment yields ranged from $202-772 \mathrm{~kg} \mathrm{ha}^{-1}$. CT plots had 3.8-fold more sediment than ST plots. Sediment curves had similar shapes as the $\mathrm{I}_{\mathrm{vSPR}}$ pattern (Fig. 3). Maximum sediment rate for $\mathrm{CT}$ and ST plots occurred 6-8 min after the 47 min $I_{v S P R}$ peak. The maximum 5-min sediment rate for CT plots was 3.9-fold higher than that for ST plots.

Comparing events, the most runoff occurred from $\mathrm{CT}-\mathrm{I}_{\mathrm{vFALL}}$ plots; the least amount of runoff occurred from the ST- $\mathrm{I}_{\mathrm{VSUM}}$ plots. The most sediment occurred from CT- $\mathrm{I}_{\mathrm{VSPR}}$ plots; the least amount of sediment occurred from the ST- $\mathrm{I}_{\mathrm{vSUM}}$ plots. Tillage impacted rainfall partitioning and detachment and transport conditions, thus runoff and sediment amounts and rates. Overall, ST reduced runoff and sediment losses for all three events as CT plots had 38\% more runoff and 2.7-fold more sediment than ST plots. ST was effective in each event (Spring, Summer, Fall) in reducing runoff and sediment. The greatest difference in runoff among CT and ST plots was 2.4-fold; the greatest difference in sediment yield among $\mathrm{CT}$ and ST plots was 3.8-fold, both for the Fall $\left(\mathrm{I}_{\mathrm{vFALL}}\right)$ event. Surface residue cover for CT and ST treatments were $<1$ and $50 \%$. The $50 \%$ surface cover associated with ST was effective in reducing the detrimental impacts of raindrop impact on a soil surface.

\section{Summary and conclusions}

We quantified runoff and sediment losses from a Tifton loamy sand managed under CT and ST and planted to peanuts at planting, 30 days after planting, after harvest with rainfall simulation events with variable rainfall intensities representative of each time period (spring, $\mathrm{I}_{\mathrm{vspp}}$; summer, $\mathrm{I}_{\mathrm{vsum}}$; fall, $\mathrm{I}_{\mathrm{vfall}}$ ). Runoff 

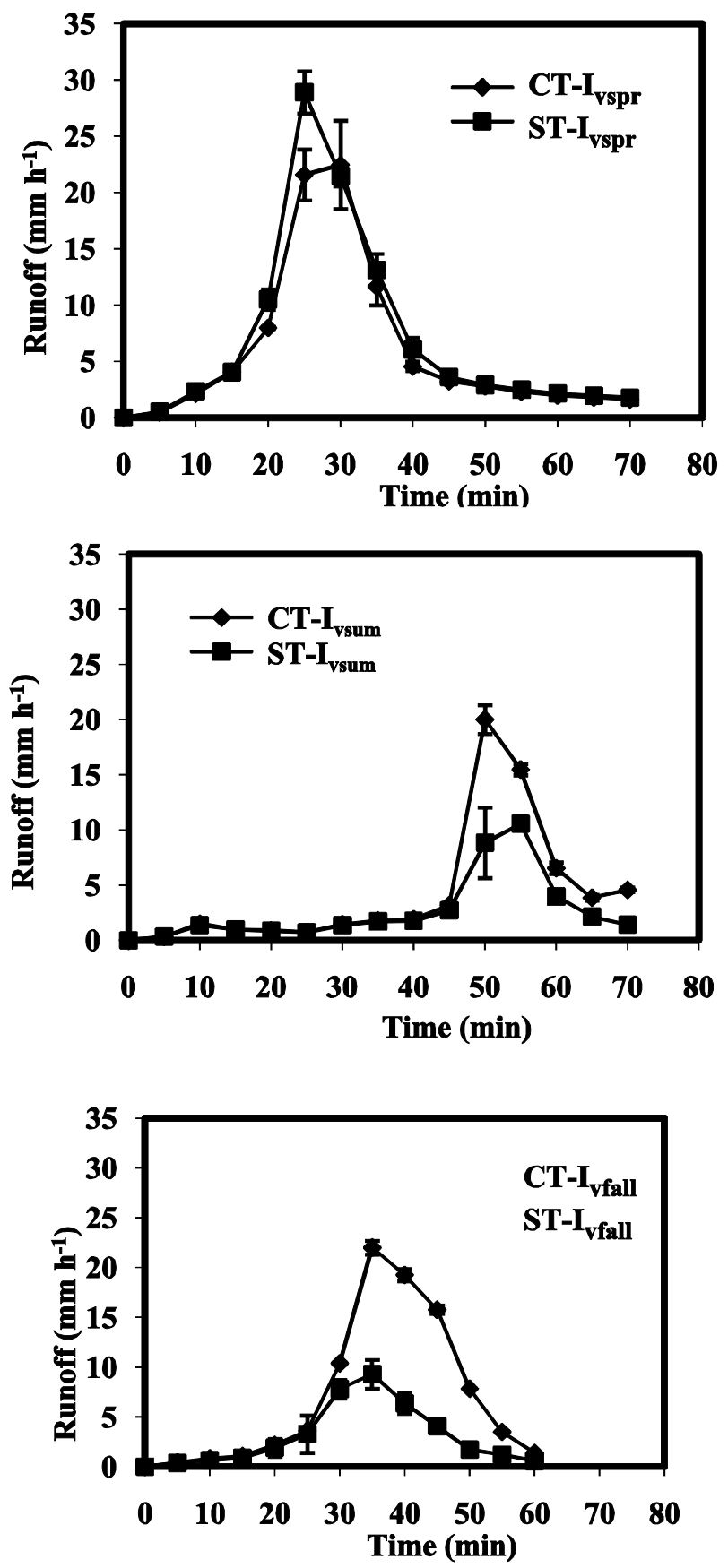

Figure 2: Runoff rates for each tillage-rainfall intensity treatment (bars $=$ standard error). 

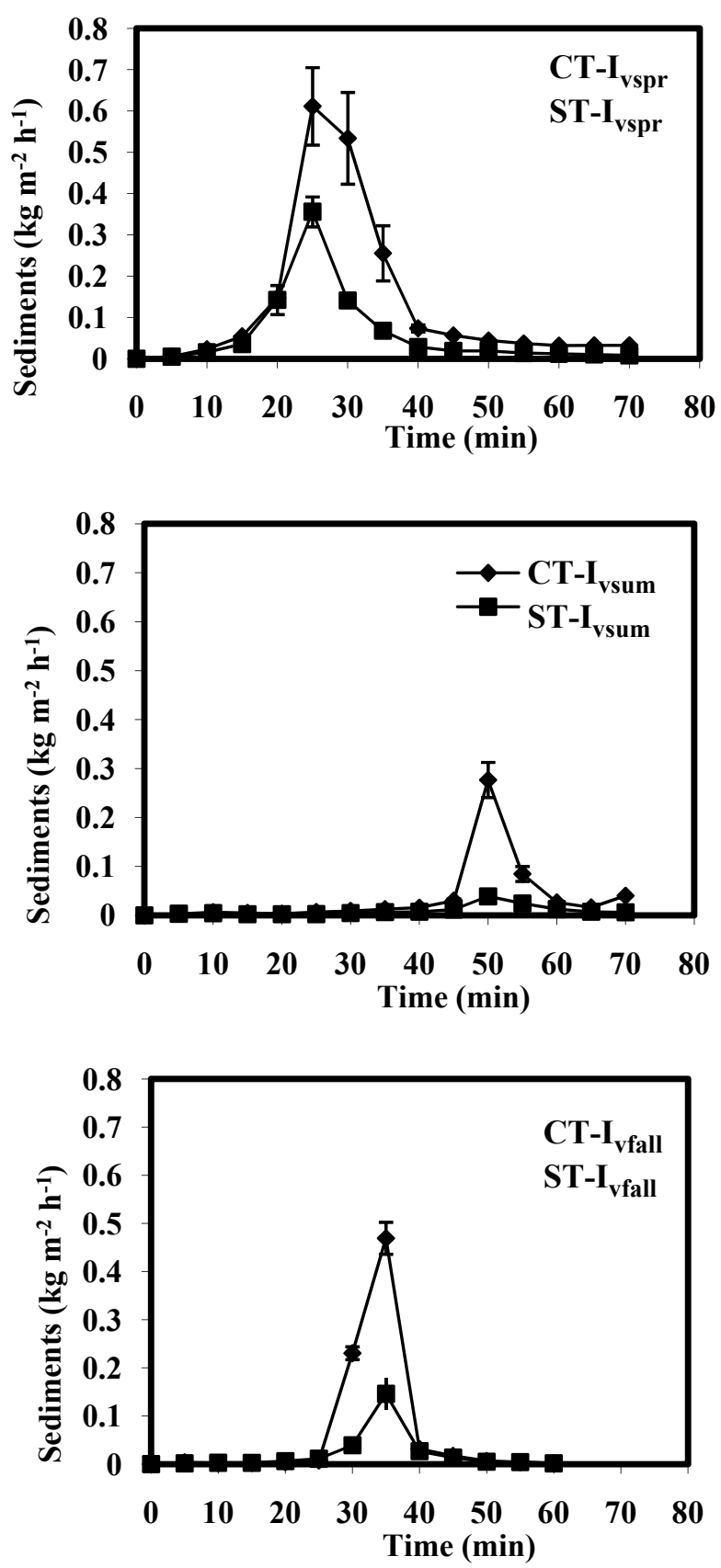

Figure 3: Sediment rates for each tillage-rainfall intensity treatment (bars $=$ standard error). 
ranged from $9-22 \%$ of the rainfall applied for the three events. The most runoff occurred from CT- $\mathrm{I}_{\mathrm{VFALL}}$ plots; the least runoff occurred from ST- $\mathrm{I}_{\mathrm{VSUM}}$ plots. Maximum runoff rates were $7-20 \%$ of the maximum intensity and occurred 3-8 min after maximum intensity peaks. Sediment yields ranged from 105-1420 $\mathrm{kg} \mathrm{ha}^{-1}$. The most sediment occurred from CT-I $\mathrm{I}_{\mathrm{vSP}}$ plots; the least sediment occurred from ST- $\mathrm{I}_{\mathrm{vSUM}}$ plots. Runoff and sediment rate curves had similar shapes as their corresponding rainfall intensity pattern. As for tillage, CT plots had 38\% more runoff and 2.7-fold more sediment than ST plots over the three events. The largest difference in runoff (2.4-fold) and sediment (3.8-fold) among $\mathrm{CT}$ and ST plots occurred from the fall event ( $\left.\mathrm{I}_{\mathrm{vFALL}}\right)$. Results improve our understanding of when runoff, sediment, and chemical losses are highest at critical times during a peanut growing season, and show how ST is effective in limiting those losses.

\section{References}

[1] Georgia Peanut Commission. 2010. www.gapeanuts.com. [verified: 12/07/2010].

[2] Reeves, D., The role of organic matter in maintaining soil quality in continuous cropping systems. Soil Till. Res. 43, pp. 131-167, 1997.

[3] Truman, C., Strickland, T., Potter, T., Franklin, D. \& Bosch, D., Variable rainfall intensity and tillage effects on runoff, sediment, and carbon losses from a loamy sand under simulated rainfall. J. Environ. Qual. 36, pp. 14951502, 2007.

[4] Truman, C. \& Nuti, R., Furrow diking in conservation tillage. Agric. Water Manage. 97, pp. 835-840, 2010.

[5] Radcliffe, D., Tollner, E., Hargrove, W., Clark, R. \& Golabi, M., Effect of tillage practices on infiltration and soil strength of a Typic Hapludult soil after ten years. Soil Sci. Soc. Am. J. 52, pp. 798-804, 1988.

[6] Cassel, K. \& Wagger, M., Residue management for irrigated maize grain and silage production. Soil Till. Res., 39, pp. 101-114, 1996.

[7] Bosch, D., Sheridan, J. \& Davis, F., Rainfall characteristics and spatial correlation for the Georgia Coastal Plain. Trans. ASAE, 42, pp. 1637-1644, 1999.

[8] Frauenfeld, B. \& Truman, C., Variable rainfall intensity effects on runoff and interrill erosion from two Coastal Plain Utlisols in Georgia. Soil Sci., 169, pp. 143-154, 2004.

[9] Nearing, M., Jetten, V., Baffaut, C., Cerdan, O., Couturier, A., Hernandez, M., Le Bissonnais, Y., Nichols, M., Nunes, J., Renschler, C., Souchere, V. $\&$ van Oost, K., Modeling response of soil erosion and runoff to changes in precipitation and cover. Catena 61, pp. 131-154, 2005.

[10] Todd, C.E., Habor, J.M., Yyner, B., 2006. Increasing magnitudes and frequencies of extreme precipitation events used for hydraulic analysis in the Midwest. J. Soil Water Conserv. 61, 179-185.

[11] Franklin, D., Truman, C., Potter, T., Bosch, D., Strickland, T. \& Bednarz, C.W., Inorganic N \& P runoff losses from variable and constant intensity 
rainfall simulations on a Loamy Sand under conventional and strip tillage systems. J. Environ. Qual., 36, pp. 846-854, 2007.

[12] Potter, T., Truman, C., Strickland, T., Bosch, D. \& Webster, T.M., Herbicide incorporation by irrigation and tillage impact on runoff loss. J. Environ. Qual. 37, pp. 839-847, 2008.

[13] Truman, C. \& Williams, R., Effects of peanut cropping practices and canopy cover conditions on runoff and sediment yield. J. Soil and Water Conserv. 56, pp. 152-159, 2001.

[14] Potter, T., Gerstl, Z., White, P., Cutts, G., Webster, T., Truman, C., Strickland, T. \& Bosch, D., Fate and efficacy of metolachlor granular and emulsifiable concentrate formulations in a conservation tillage system. J. Agric. Food Chem. 58, pp. 10590-10596, 2010.

[15] Systat, 2004. SigmaStat. 3.1. Systat Software. Point Richmond, CA. 